\title{
„Mocna" i „słaba” interpretacja duchowości a nauki o wychowaniu
}

\begin{abstract}
Abstrakt
We współczesnej, zsekularyzowanej kulturze Zachodu coraz częściej mówi się o duchowości jako duchowości bezreligijnej czy nowej duchowości, zwracając uwagę na jej przeżywanie w pierwszej osobie, zazwyczaj w odniesieniu do wartości z obszaru egzystencjalnego. W artykule takie pojmowanie duchowości zostaje skonfrontowane z zaproponowanymi dwoma jej sposobami interpretacji - „mocną” i „słabą”, przy uprzednim określeniu ram samej interpretacji z perspektywy hermeneutycznej. W kontekście tych interpretacji zostało m.in. sformułowane pytanie o obecny status kategorii duchowości w naukach o wychowaniu, które źródłowo są naukami humanistycznymi. Aby jednak móc dotrzeć do duchowości jako „stałej ludzkiego życia” w przenikaniu się jej obecności i nie-obecności, wydaje się być koniecznym wywłaszczenie jej ze zwyczajowych konceptualizacji.
\end{abstract}

Słowa kluczowe: duchowość, interpretacja, myśl „mocna”, myśl „słaba”, humanistyka, nauki o wychowaniu.

\section{"Strong" and "Weak" Interpretation of Spirituality and the Educational Sciences}

\begin{abstract}
In contemporary, secularized Western culture, more and more people talk about spirituality as non-religious or new spirituality, paying attention to its experience in the first person, usually in relation to existential values. In the article, this understanding of spirituality is confronted with two proposals of ways for its interpretation - the "strong" and the "weak", with the prior definition of the framework of the
\end{abstract}

\footnotetext{
* Uniwersytet Łódzki.

Artykuł otrzymano: 3.11.2020; akceptacja: 21.12.2020.
} 
interpretation itself from the hermeneutic perspective. In the context of these interpretations, a question is formulated about the current status of the category of spirituality in educational sciences, whose source is in the humanistic sciences. However, in order to be able to reach spirituality as "the constant of human life" in the permeation of its presence and non-presence, it seems necessary to expropriate it from the usual conceptualizations.

Keywords: spirituality, interpretation, "strong" thought, "weak" thought, humanities, educational sciences.

„(...) pewne stałe ludzkiego życia pozostały niezmienne, a nauka nie przybliża nam ich bardziej niż poetyckie opowieści".

Emil Cioran (2015: 185)

„(...) za naukowe uważam tylko uznawanie tego, co jest, nie zaś wychodzenie od tego, co powinno lub mogłoby być.

W tym sensie staram się (...) rozważać z zasadniczą ogólnością to, co dzieje się zawsze".

Hans-Georg Gadamer (1993: 458)

\section{Wprowadzenie}

Dlaczego duchowość? Czy współcześnie duch i dusza straciły swoją sakralną dźwięczność w językach nauki, jak i w cioranowskich „poetyckich opowieściach” na rzecz wybrzmiewającej w zsekularyzowanym świecie kultury Zachodu duchowości? Tej nie łączy się już tylko z życiem religijnym, zwłaszcza z jego pogłębionymi vel wyjątkowymi (aż po mistyczne) formami, które zazwyczaj są dostępne osobom stanu duchownego, żyjącym w izolacji od „twardej” rzeczywistości. O niej samej mówi się, że jest duchowością bezreligijną lub że jest nową duchowością, o której można zaświadczyć przez pryzmat jej przeżywania w pierwszej osobie w odniesieniu do wartości z obszaru egzystencjalnego, który ma znaczenie istotowe dla człowieka i - jeśli jest powiązany z transcendencją, to w innej jej wykładni niż tej preferowanej przez zachodnie kościoły ${ }^{1}$. Duchowość $\mathrm{w}$ takim ujęciu wskazuje na człowieka przeżywającego to, czego potrzebuje i pragnie i za czym tęskni jego zeświedczona dusza.

W tym miejscu warto wspomnieć o tropieniu przez Jacquesa Derridę znaczeń ducha (Geist) i duchowości (geistlische) w twórczości Martina Heideggera, których wykładni towarzyszyła intencja zdechrystianizowania. Zdaniem Derridy Heidegge-

\footnotetext{
${ }^{1} 0$ duchowości pozareligijnej, nowej duchowości patrz: np. Baniak (red.) 2012; Grzegorczyk, Sójka, Koschany (red.) 2006; Leszczyńska, Pasek (red.) 2008. Czytelnika odwołuję do artykułu Janusza Mariańkiego $O$ nowej duchowości - próba opisu zjawiska, który ukazał się w niniejszym numerze „Nauk o Wychowaniu. Studia Interdyscyplinarne".
} 
ra wypowiedzi o duchowości - często niebędące wypowiedziami dosłownymi tylko „okrężnymi” i metaforycznymi, są lokowane między „platońsko-chrześcijańskim, metafizycznym lub onto-teologicznym określeniem duchowości (geistig) a inną myślą o duchowości (...) chodzi o geistlische, tym razem oderwane - jak chciał tego Heidegger - od swojego chrześcijańskiego czy kościelnego znaczenia"2 (Derrida 2015: 110). Signum temporis - znak/i znamię czasu?

Bez względu na zwyczajowe relacje duchowości do sfery sacrum - w kulturze Zachodu tradycyjnie kojarzonej właśnie z religią chrześcijańską, a także, choć zdecydowanie rzadziej, z religiami przedchrześcijańskimi i pozachrześcijańskimi - współcześnie wiąże się ją z osobistym doświadczeniem egzystencjalnym, często wewnętrznym i intymnym, lokującym się także poza zinstytucjonalizowaną religią. Wszak ono może się zakorzeniać w religijności człowieka, o czym pisał Karl Gustaw Jung (2020) odwołujący się do twórczości swego przyjaciela Mircea Eliade’a i twierdzący, że jest to jedna z prawomocnych dla całościowej kondycji człowieka funkcja jego psyche.

W jaki sposób można interpretować duchowość, mając świadomość, że pytającym jest człowiek kultury Zachodu?

\section{Interpretacja i jej polifoniczny charakter}

W hermeneutyce o interpretacji - rozumianej za Paulem Ricoeurem (1989) jako dialektyka rozumienia i wyjaśniania, w której znaczenia czegoś nie są odkrywane, a wytwarzane 3 - można mówić wówczas, gdy to, czego ona dotyczy, jest ulokowane w kulturze wewnętrznie zróżnicowanej.

Tylko taka bowiem kultura stawia w ogóle problem interpretacji, ponieważ tylko na jej gruncie może wystąpić wielość interpretacji. Tam, gdzie tej ostatniej nie ma, nie można dostrzec tego, że coś takiego jak interpretacja w ogóle istnieje, albowiem cały świat tworzy niepowątpiewalną całość noszącą znamiona naturalności i oczywistości (nic nie może być inne niż ,jest"). (...) Nie przypadkiem zatem problem interpretacji nasila się wtedy, gdy kultura ulega pluralizacji, jak to było w starożytnej Grecji, czasach Reformacji czy w epoce ponowoczesnej różnorodności (Szahaj 2012: 93-94) .

\footnotetext{
2 Zdaniem Derridy, choć Heidegger nie odrzucał określenia ducha jako spiritus i pneuma, to w jego twórczości nie można jednak uchwycić utożsamiania przez niego spiritus z pneumq (Derrida 2015: 21).

3 Ricoeur uważa, że interpretacja pojawia się wówczas, gdy nie wystarcza zwykłe, bezpośrednie rozumienie czegoś, gdy trzeba przejść do jego wyjaśniania, które jest jakby etapem pośrednim między tą pierwszą formą rozumienia a drugą - rozumienia pojmowanego w sensie orientowania się w świecie.

4 Por. z wypowiedzią Gianni Vattimo: „(...) myśl, która - śladem Heideggera - pojmuje bycie jako to, do czego nigdy nie da się dotrzeć w obecności” jest myślą, której przedmiot „jest jedynie przedmiotem rozpamiętywania" (Vattimo 2015: 144).
} 
Każda interpretacja jest zaimpregnowana kulturową powłoką, wytworzoną i podzielaną intersubiektywnie. W kulturze wewnętrznie zróżnicowanej powłok impregnujących interpretacje jest wiele. Wytwarzane i podzielane intersubiektywnie „kryją” i zarazem „odsłaniają” wizje rzeczywistości, często do siebie niewspółmierne - choćby ze względu na ich usytuowanie w uprzywilejowanych kontekstach kulturowych i tych niszowych. Clifford Geertz, powołując się na Wittgensteinowską teorię gier językowych, pisze o „układzie społecznych interakcji”, „dyskursywnych wspólnotach”, „intersubiektywnych systemach odniesienia”, w których „coś jest czymś dla jakiegoś ty i jakiegoś ja”, będąc „uformowane przez potok zdarzeń”. Ten „sposób wytwarzania świata” może zaistnieć jedynie poprzez „społeczną konstrukcję znaczeń”, którą w tym miejscu określę jako wielką narrację, będącą wizją rzeczywistości, jak również jej fragmentu (Clifford 2003: 99; por. Straś-Romanowska, Bartosz, Żurko 2010). Wśród nich są te, które wiodą prym, jak również te, które wyłaniają się, i te, które są kontestującymi. Wydaje się, że wciąż do niszowej wizji rzeczywistości należy ta, o której Andrzej Szahaj pisze, że jest konsekwencją „przewrotu kopernikańskiego w filozofii, szerzej - w humanistyce, czy wręcz w całym zachodnim poznaniu", lecz z którą trudno jest się pogodzić, bo podważa ludzkie przywiązanie do własnych mocy poznawczych. Szahaj pisze: „rzeczywistość sama w sobie jest niepoznawalna, zaś poznawalne jest tylko to, co sami do niej wnosimy" (Szahaj 2012: 89). Lecz ta niby dowolność jest uwarunkowana historycznie i kulturowo, „gęsta” od kanonów znaczeń, z dominacją kanonu sensu właściwego także poznaniu ludzkiemu. Ponadto nie wszystko poddawane jest interpretacji, a może inaczej - nie wszystko zasługuje na to, „by być w jakikolwiek sposób interpretowane (dlatego właśnie, że interpretuje się mając na uwadze jakiś sens)" (Ferraris 2015: 211). Odpowiedź na pytanie: czym jest rzeczywiście to, co człowiek widzi, czuje, słyszy et cetera, nie jest jeszcze interpretacją. Interpretację - jak powie Murizio Ferraris - pojąć można „w intencjonalnym znaczeniu wyobraźniowych wariacji" i wówczas fakty pozostają faktami: człowiek widzi, czuje, słyszy et cetera, a interpretacja będzie przedstawieniem czegoś jako czegoś - przedstawieniem np. tego, że człowiek widzi, czuje, słyszy et cetera jako niezbywalnych modalności jego fizykalnego (cielesnego) związku z rzeczywistością, w której żyje. Wypada również zwrócić uwagę na to, że przedmiotem interpretacji - w ujęciu hermeneutycznym, o czym pisze Luigi Pareyson - „nie jest byt, lecz stosunek człowieka do bytu” - jego bycie w relacji do bycia czegoś (Pareyson 2015: 103). Czym zatem jest interpretacja, jeśli nie jest wyjaśnieniem/wykładnią tego, czym coś jest (w najbardziej potocznych tych słów znaczeniach)? Idąc dalej za Pareysonem - choć nie tylko za nim - przyjęłam, że jest „prze-myśleniem” u podstaw kultury, w której się dokonuje, choćby towarzyszyła temu konstatacja i dekonstrukcja, i kulturową „wypowiedzią" - dającą sobą świadectwo starych i/lub nowych jej znamion. Takie ujęcie koresponduje z wcześniej przytoczonym ujęciem interpretacji Ricoeura. 
Hermeneuta - głównie o proweniencji gadamerowskiej i ricoeurowskiej - powiedziałby, że interpretacja jest zawsze „czyjaś”, w tym znaczeniu, że jest uwarunkowana naszą wrażliwością, predyspozycjami poznawczymi i mentalnymi oraz językowymi. Idąc za Szahajowskim spostrzeżeniem, skonstatuję, że to, na co człowiek jest uwrażliwiony, co może poznać i objąć mentalnie oraz o czym może się wypowiedzieć, istnieje dla niego przez pryzmat nadawanych znaczeń przez niego samego. Nie jest on jednak rozbitkiem na bezludnej wyspie, jest bowiem ulokowany w Cliffortowskim „układzie społecznych interakcji”, „dyskursywnych wspólnotach”, „intersubiektywnych systemach odniesienia” et cetera, które - patrząc z perspektywy hermeneutycznej, ale z nieco innego obiektywu - pretendują do kruchej intersubiektywności.

Choć o interpretacji można byłoby napisać jeszcze wiele, wskazując na jej nie tylko historię, ale przede wszystkim współczesną wykładnię/współczesne wykładnie, to uznałam, że tak zakreślone jej ramy są wystarczające, by w końcu zapytać o to, czy duchowość istnieje poza jej interpretacjami z uprzednimi założeniami o znaczeniu/sensie duchowości, ale które zarazem to znaczenie/sens w interpretacji duchowości jest nadawany-udowadniany? Czy jest możliwe wypowiadanie się o duchowości oczyszczone z uprzedniego nadawania jej znaczeń? Kiedy Gianni Vattimo mówi o interpretacji jako „fabularyzacji świata”, opowiada się za kontekstualizacją świata jako kompozycją jego wyobrażeń, u podstaw której odnajdujemy „ponowne przemyślenie sensu bycia” jako obecności „albo przynajmniej zapomnienia o nim" (Vattimo 2011: 23-24). Tak ujęta interpretacja powinna rozpoznawać także granice swego zastosowania w obszarze będącym zarazem przedmiotem fabularyzacji ${ }^{5}$. Żadna interpretacja nie wyczerpuje bowiem aspektów i niuansów bycia czegoś - to w niej dokonuje się powołanie czegoś do bycia jako czegoś, czyli do generowania znaczeń tegoż bycia. Interpretacja nie jest transparentna - nie przylega przejrzyście do obecności swojego przedmiotu. W hermeneutyce współczesnej - o czym pisze Paweł Dybel - przedmiot interpretacji wyłania się z „nieustannego różnicowania się i stapiania ze sobą odmiennych horyzontów [jego - A.W.] rozumienia, nie dając się sprowadzić do postaci określonej ontologicznej struktury o stabilnym i niezmiennym charakterze" (Dybel 2012: 22). Sens tego, co jest przedmiotem interpretacji, nie jest uwarunkowany ani jego faktycznością - w tym miejscu rozumianej jako „twarda” obecność, ani jej wyobrażeniem, któremu nadając pozytywną konotację, przypisuje się moc inwencji w rzeczywistość, w której żyje człowiek. Sens przedmiotu interpretacji jest „wynaleziony”, a nie znaleziony, odkryty, odtworzony. Jest on (dopiero) możliwy, a to, co możliwe w spektrum jego rekonfiguracji i konfiguracji - jak powiedziałby Ricoeur - jest równie wiarygodne, choć często niemożliwe do zrealizowania w aktualnym po-

\footnotetext{
5 Ramy artykułu nie pozwalają podjąć w tym miejscu bardzo istotnego wątku: etyki narracji, na co szczególną uwagę zwraca się/zwracało się w filozofii postmodernistycznej.
} 
rządku świata (Ricoeur 2008: 276). Dlaczego? Ricoeur mógłby - jak mi się wydaje - odpowiedzieć na to pytanie z obszaru wcześniejszej swojej twórczości, lecz i on sformułował pytanie bez jednoznacznej odpowiedzi: „Jaki jest sposób bycia bytu, który istnieje tylko przez rozumienie?" (Ricoeur 1989: 207). Sens nie jest zatem przedmiotem rozumienia - on jest tym, wokół czego organizuje się rozumienie. A to oznacza otwarcie przed interpretatorem nowych możliwości rozumienia. W hermeneutyce podkreśla się, że nie jest możliwe „w oparciu o określoną technologię rozumienia, teorię czy metodę, wypracować takiej interpretacji czegoś, która czyniłaby jego sens całkowicie przejrzysty" (Dybel 2012: 82).

Czy Cioranowskie „pewne stałe ludzkiego życia”, które pozostały niezmienne, posiadają stabilną i określoną ontologiczną strukturę, pozwalającą na ich (pełne) rozpoznanie i nazwanie, czy raczej są niezmienne, dlatego że wciąż sprawiają człowiekowi kłopot? Język kultury Zachodu stara się uporać z wszelką aporetycznością/obcością/innością, która się jemu narzuca jako symbolicznemu wytworowi człowieka. Będąc „przywykłym” do pojęć określających to, co się da nazwać i tym samym zamykających rzeczywistość w dogmaty językowe, to co wymyka się spod jego władzy nazywania, lokuje w „poetyckich opowieściach”. Jednak i z pojęciami jest kłopot. Wiele pojęć - i takich „wędrujących” między dyscyplinami oraz dyskursami ${ }^{6}$, i zagnieżdżających się w nich, i w nich „obumierających”, bo np. nie na czasie, więc nie modne, i wymykających się z nich et cetera - wprowadza w zakłopotanie: są, a nie można się z nimi uporać, choćby ze względu na płynność ich znaczeń i znaczącą różnicę ich sensów. Tym bardziej, że w trakcie wędrówki między dyscyplinami pojęcia i teorie nie tylko zmieniają zakres znaczeniowy, lecz także wchodzą w nowe, często zaskakujące, interakcje i tym samym ich bycie jest ponownie usytuowane. Transformacja znaczeń dokonuje się także w przestrzeni przekraczania granicy między tym, co naukowe, a tym, co mieści się w czaso-przestrzeni codziennego doświadczania człowieka. Podobnie jest z pojęciami: duchowość, a także: dusza/duch/rozwój duchowy.

Niezmienne „stałe ludzkiego życia” - idąc ścieżką inspiracji hermeneutycznej - nie posiadają znamion „naturalności i oczywistości”. Odwracając wypowiedź Szahaja - „stałe ludzkiego życia” mogą być inne niż „są”, o innych znaczeniach nadanych przez człowieka. Jeśli przyjąć za Szahajem, że w rzeczywistości „poznawalne jest tylko to, co sami do niej wnosimy”, to „stałe ludzkiego życia” jako nie-

\footnotetext{
${ }^{6}$ Zdaniem Miekie Ball (2013) pojęcia i teorie wędrują między dyscyplinami, a także między uczonymi, także tymi, którzy sytuują się $\mathrm{w}$ różnych geograficznych społecznościach naukowych. W ten sposób rodzi się debata nad potencjałem pojęć, które mają moc przekraczania ograniczeń dyscyplinarnych. Do nich - moim zdaniem - należą również te pojęcia, które są zamarłe, wyświechtane, zbagatelizowane, odświętne, sztandarowe, na marginesie głównych dyskursów et cetera. To pojęcia, z którymi zazwyczaj jest kłopot - mimo wszystko są i coś znaczą i nabierają także nowych znaczeń, choćby były marginalizowane czy wykluczane przez dominujące dyskursy. Powroty do nich i zwroty ku nim okazują się/mogą okazać się ważne dla zmian w dyskursie/dyskursach, w których stanowią kłopot lub po prostu są w nich już nieobecne, jednak „odbijają się czkawką”.
} 
zmienne są właśnie rozpoznane jako niezmienne, czyli obecne w życiu człowieka. Sama zaś kategoria ich obecności nie musi być tożsama ze stabilną i określoną ontologiczną strukturą, a w kontekście hermeneutycznym - nie jest tożsama. Jeśli w tym miejscu przyjmiemy, że duchowość jest Cioranowską niezmienną „stałą ludzkiego życia" i mając powyższe na uwadze, to - powtórzę - z jakimi interpretacjami duchowości możemy się spotkać współcześnie?

W kręgu hermeneutycznym - choćby za Gadamerem i Ricoeurem - przywykło się nadawać interpretacji postać językową zgodnie z przyjętym założeniem, że świat zostaje udostępniony człowiekowi w medium języka. Biorąc pod uwagę dziejowość interpretacji - to znaczy zmianę w obrębie jednej interpretacji, jednego nurtu interpretacji, ale także zmianę w interpretacyjnym nastawieniu do rzeczywistości i tworzenie się narracji na skrzyżowaniu tych nastawień i/lub w opozycji do tych, które wiodą prym w kulturze - można mówić o polifonii języków interpretacji. Są jednak języki zastane i obeznane, uprzywilejowane, pożądane, właściwe et cetera, i te - o czym wcześniej już napisałam - niszowe. Będąc wytworem kulturowym, język dominujący to ten, któremu w danym czasie zrobiono miejsce w kulturze. A to oznacza, że jest on nie tylko wytwarzany przez „układ społecznych interakcji”, w „dyskursywnych wspólnotach”, „intersubiektywnych systemach odniesienia" et cetera, ale także je konstytuuje.

Znaczenia temu, co było, jest i będzie są zatem nadawane w leksykalnym i semantycznym kontekście kultury, w których żyje człowiek i które tworzy/projektuje, również wtedy, kiedy kontestuje kulturę - przecież robi to przy użyciu języka. W ten sposób znaczenia są nadawane także duchowości, duszy, duchu, sferze duchowej, temu, co duchowe et cetera. Z kontekstu kulturowego, będącego kontekstem czasowego ich użycia, wynikają także podobieństwa i różnice znaczeń czytelnych dla tych, którzy pozostają w tym kontekście ${ }^{7}$. Jak język kultury Zachodu, „przywykły” do pojęć, interpretuje duchowość, która zarazem jest obecnością na warunkach uznanych przez człowieka (por. Maldjieva 2019)?

Inspirując się koncepcją myśli słabej versus mocnej we włoskiej hermeneutyce Gianni Vattimo i Maurizio Ferrarisa (Surma-Gawłowska, Zawadzki 2015), kojarzonych z nurtem późnej nowoczesności lub postnowowczesnym, podejmuję próbę oglądu „mocnej” i „słabej” interpretacji duchowości, z czym nierozerwalnie wiąże się również to, co o niej się (nie)mówi w kontekście pytań o jej obecność versus nieobecność.

\footnotetext{
7 Widzę tutaj paralelę z wypowiedzią Ludwika Wittgensteina: „Czy jednak pełny kształt zdania nie był zamierzony np. już na jego początku? (...) Zamiar jest osadzony w sytuacji, w ludzkich zwyczajach i instytucjach. Gdyby nie było techniki gry w szachy, to nie mógłbym zamierzać grać w szachy. Jeśli forma zdania jest z góry zamierzona, to jest to możliwe dzięki temu, że umiem mówić po niemiecku" (Wittgenstein 2012: 156, § 337).

${ }^{8}$ W tym miejscu wypada również wskazać Piera Aldo Rovattiego. W artykule nie przytaczam jednak jego wypowiedzi.
} 


\section{„Mocna” interpretacja duchowości}

Co znaczy duchowość? W tym pytaniu jest już obecne przedzałożenie, że duchowość coś znaczy/ma znaczyć tak jak np. znaczy dla kondycji egzystencjalnej człowieka rozwój intelektualny, fizyczny czy społeczny. Jest ona stabilna w byciu, w którym jest obecna, a obecności tej człowiek nadaje fundamentalistyczne i esencjalistyczne atrybuty. Jest tym, co faktyczne w ludzkim sposobie doświadczania rzeczywistości, w tym i własnej kondycji człowieka. Faktyczność obecności duchowości można rozumieć jako bycie „tu teraz” w świecie, przez które przenika czas przeszły i przyszły, w tym znaczeniu, że można „oglądać” jej przejawy w przeszłości w postaci np. biografii osób uznanych za uduchowionych, mistyków, mądrych duchem, jak i w przyszłości w postaci np. określenia własnego kierunku rozwoju duchowego. Jako bycie w formie pierwotnej jest ono rzucone w świat i tym samym jest czymś oczywistym, a to oznacza, że kontakt $\mathrm{z}$ duchowością jest w zasięgu możliwości człowieka, który również jest obecnością w świecie.

W uniwersalnej wizji porządku świata, który organizują „mocne” - fundamentalne - kategorie ontologiczne, obecność duchowości jest pożądaną referencją człowieczeństwa, przy uprzednim jej rozpoznaniu poprzez identyfikację jej znaczeń poddanych intelektualnym (mentalnym) obróbkom lub pozostających w sferze ich intuicyjnego przeżywania (Ricoeur 2004: 5-15). Jeżeli zaś duchowość jest tym, co poddaje się identyfikacji - jest ona rozpoznana i ujęta w pojęcie - to ona sama jest jakoś dana człowiekowi w jego procesie poznania i/lub przeżywania, niezależnie od tego, czy staje się ona przedmiotem jego pytania o nią. Oznaczałoby to, że duchowość „zwraca się” ku człowiekowi - tak jak o wartościach autotelicznych mówili fenomenolodzy tacy jak Max Scheler, Dietrich von Hildebrand, Nikolai Hartmann i inni, także niezwiązani z nurtem fenomenologicznym. A może człowiek - z troski o swoje bycie-w-świecie - zwraca się ku duchowości i podąża ku niej, po uprzednim nadaniu jej znaczeń dla swojego rozwoju w kanonach kulturowo zakreślonych ram człowieczeństwa? Duchowość może być jednak inna niż wtedy, kiedy jest dana w naszym jej przeczuwaniu, przeżywaniu i poznaniu. To jednak rzutuje na to, że jej faktyczność pozwala tylko na jej opisanie.

Umieszczenie znaczeń „wewnątrz” duchowości implikuje odnajdywanie ich potwierdzenia w życiu człowieka, które - aby było wartościowe - ma być właśnie ukierunkowane na duchowość. Duchowość uznano za substancjalnie istniejącą. Ponadto nadano jej właśnie znaczenie - jest uprzywilejowanym sposobem bycia człowieka spełniającego się w swym człowieczeństwie. Człowiek podąża ku duchowości jako pożądanej formy swego pełnego bycia i takim siebie potwierdza (może potwierdzać) na drodze realizacji wartości, które jako najwyższe w hierarchii określa się mianem wartości duchowych o charakterze autotelicznym - dóbr samych w sobie. Zaryzykuję stwierdzenie, że znaczeniowość duchowości jest efektem myślenia życzeniowego człowieka - oto duchowość ma znaczyć dla jego egzystencjalnej kondycji i kwestią zasadniczą dla zasadności podejmowanych 
działań w kierunku jej rozwoju jest pytanie: „co czynić, aby w życiu człowieka znaczyła?”. Kiedy pojawia się myślenie życzeniowe? Za Heideggerem można powiedzieć, że pojawia się ono wtedy, kiedy do głosu dochodzi świadomość problematyczności swego bycia-w-świecie, które nieuchronnie jest byciem skończonym. I być może to nie duchowość jest Cioranowską „stałą ludzkiego życia”, a właśnie problematyczność własnego bycia-w-świecie, które „wytwarza” inną „stałą” - duchowość. Wówczas ma ona znaczenie egzystencjalne.

Duchowość - wybrzmiała jako to, co konstytuuje człowieczeństwo w człowieku, nawet wówczas, gdy o jej obecności mówi się jako obecności ponad-rzeczywistej, do której ma się jednak dostęp poprzez np. ćwiczenia duchowe/ćwiczenia duszy - jest uzusem językowym w obrębie współczesnej kultury Zachodu. Także takie pojęcie jak „rozwój duchowy”, wpisywane w kontekst rozważań o duchowości, jest kulturowym konstruktem językowym - klarownym, uniwersalnym i pragmatycznym. To pojęcie jest trwałe i trudno podważyć zawarte w nim przesłanie, o czym świadczy trudność zmiany przekonania o pozytywnej waloryzacji słowa „rozwój” (a dalej jego pojęcia) wpisanego w progresywną wizję człowieka - podmiotu skoncentrowanego na sobie i zdolnego także do samorozwoju, z czym pojęcie rozwoju duchowego bezpośrednio się wiąże. Pojęcie to jest także dystrybutorem uzasadnień oddziaływań wychowawczych, edukacyjnych, profilaktycznych, resocjalizacyjnych, terapeutycznych et cetera. Interpretacja rozwoju duchowego staje się zatem inwencją - „dopisywaniem” i/lub „przepisywaniem” jego znaczeń, celowym nad-dawaniem znaczeń, również na drodze re-deskrypcji zastanych znaczeń (por. Szajnert 2006).

„Mocna” interpretacja duchowości vel rozwoju duchowego ma charakter konkluzywnych odczytań ich znaczeń dla kondycji ludzkiej egzystencji. Dysponuje językowymi imperatywnymi narzędziami generującymi ogląd, interpretację i konceptualizację rzeczywistości, w której ludzka egzystencja ma szansę stać się egzystencją w pełni człowieczą - współbrzmiącą dzisiaj z hasłami eco-humanizmu. Opis duchowości, przy uprzedniej jej interpretacji jako stanu możliwego do osiągnięcia, bo obecnego w zasięgu ludzkich możliwości „przetwarzania siebie”, jest instrumentalny w rozgrywce między Frommowskimi biegunami „być czy mieć” na różnych liniach ich interpretacji i przesunięciach interpretacyjnych ${ }^{9}$. I choć zmienia się/może zmieniać się zakres treściowy kategorii „być”, powiązany ze sferą duchowości człowieka, to ona sama jest wyrażana językiem ją projektującym przy zastosowaniu językowego instrumentarium: pojęć wartości, celów, a także powinności. Duchowość jest dostępna człowiekowi - jest mu dana jako obecność w przestrzeni, w której żyje, a język, w którym o niej się mówi, wskazuje także na to, jak do niej dotrzeć.

\footnotetext{
9 M. Ball (2013), pisząc o wędrujących pojęciach w humanistyce, zwraca uwagę na ich niezmienność leksykalną - wciąż brzmią tak samo, i zmienność semantyczną - ich zawartość treściowa ulega zmianie.
} 


\section{„Słaba” interpretacja duchowości}

W „myśli słabej” postulowano radykalne przemyślenie problemu bycia, zapoczątkowanego jeszcze przez Heideggera w jego głównym dziele z pierwszego okresu twórczości w Byciu i czasie. Zapytano o stabilność obecności i istotowość bycia (w byciu), a odpowiedź, jakiej udzielił Vattimo o byciu, wynikała z krytyki jego stabilności i istotności sprowadzonych do uogólnienia tego, co jest dane w obecności i co jest samą obecnością (Vattimo 2015). Bycie nie jest, lecz staje się, zdarza czy też przydarza się, wy-darza się, będąc warunkowane nieskrytością/otwartością bytu, który jawi się, odsłania się egzystującemu człowiekowi. Bycie nie jest bytowe - nie ma stabilnej struktury. Również myśl o nim nie uobecnia go - ono „przejawia się” jako przesłanie: „[b]ycie nie jest, lecz się przekazuje (wyrusza w drogę i wysyła siebie), przesyła się", jak twierdzi Vattimo, nawiązując wprost do Heideggera i jego ujęcia wy-darzania bycia (tamże: 139; por. Walczak, Jocz 2019: 88-98)). Sens bycia jest rozproszony, a zatem nie ma także możliwości oznajmienia, że istnieje albo nie istnieje. Znacząco wybrzmiewa w tym miejscu pytanie, które sformułował Ricoeur w kontekście swoich rozważań o rozumieniu niebędącym odtworzeniem tego, co ktoś myśli i czuje, czy jakie coś jest, lecz będącym sposobem ludzkiego bycia-w-świecie: „Jaki jest sposób bycia tego bytu, który istnieje tylko przez rozumienie?” (Ricoeur 1989: 207).

Idąc tym tropem, „odmówimy” również duchowości formy bytu - jest formą bycia, a raczej przydarza się jako bycie, wy-darzając się - dziejąc się, co jednak nie oznacza literalnie tego, że nie jest faktycznością. Jest formą „obecności” niesamodzielnej, zawsze tylko możliwej, bo zapośredniczonej także w niewiedzy człowieka o tym, co mu się w przygodności bycia przy-darzy.

Kluczowe pytanie: „jak jest dana człowiekowi duchowość?”, przy założeniu o usytuowaniu duchowości i człowieka na linii ich wzajemnej relacji, wskazuje na jej obecność przenikaną przez jej nie-obecność. Próbę odpowiedzi na to pytanie trzeba jednak poprzedzić poszukiwaniem odpowiedzi na pytanie: „jak coś, co się wy-darza, może być obecnością pojmowaną jako faktyczność, inaczej jednak ujętą niż w „mocnym” sposobie interpretacji duchowości?”. W odpowiedzi na to pytanie proponuję uwzględnić możliwe relacje: człowiek - duchowość ze względu na „niesamodzielność” bycia duchowości:

- obecność duchowości to bycie „w-obec” człowieka - ma ona zatem charakter lokacyjny (jest usytuowana w życiu człowieka, ale ze względu na jego relację do niej) i partycypacyjny (bierze udział w tym życiu - również ze względu na jego odpowiedź na przeżycie tej relacji) (Wojtysiak 2005: 156-160),

- bycie „w-obec” sygnalizuje bliskość jej bycia z byciem człowieka, który swoim byciem potwierdza jej obecność,

- bycie „w-obec” nic nie mówi o jakości jej bycia - bycia o wyróżnionym zespole przymiotów/atrybutów. 
O faktyczności obecności duchowości w świecie człowieka zaświadcza interakcja jej jakości przejawiających się i uchwytnych w „tu teraz” lub w czasie odleglejszym. Jej przeżywaniu towarzyszy „szczególny czas teraźniejszy”, który jest (może być) także czasem kolejnego przeżywania jej wydarzania się w planie osobistego życia. „Teraz” obecności duchowości może być obecne w sferze przeżyć człowieka niezwiązanych z bezpośrednim dla nich, kalendarzowym „tu teraz”. Obecność duchowości może być odnaleziona po czasie, o czym krótko piszę dalej. „Teraz” znamionuje szczególną jednorazowość wydarzania się duchowości, która staje się obecnością - „ten raz obecność jest taka, innym razem inna” (Brejdak 2007: 47) ${ }^{10}$. Zadziwiająca to obecność w czasie, gdzie jej bycie określa się w jego nieciągłości, niestałości, zmienności i różnorodności. Ta faktyczność bycia jednak - w ujęciu Quentina Meillassoux - nie daje się sprowadzić do przygodności, która dotyczy „wszystkiego, co może w świecie być lub nie być, wydarzyć się lub nie wydarzyć” i która „pozwala dostrzec «możliwość» Inaczej świata, i to w obrębie tegoż świata” (Meillassoux 2015: 64-65). Dalej o przygodności Quentin Meillassoux pisze tak:

Przygodność w sumie polega na tym, że coś się w końcu przydarza - coś innego, co wymykając się wszystkim sklasyfikowanym dotychczas możliwościom, kładzie kres próżnej grze, w której wszystko, również to, co nieprawdopodobne, jest do przewidzenia. (...) Taka jest przygodność: wszystko może się wydarzyć, nawet jeśli nic się nie wydarza, a to, co jest, pozostaje takie, jakie jest (Meillassoux 2015: 156, 94-95) ${ }^{11}$.

Powyższe ujęcie przygodności koresponduje, choć niedosłownie, z tym, co Vattimo pisał o wy-darzaniu, które dla niego - idącym po śladach Heideggera - „jest tym, co towarzyszy - jako ułomność - wszelkim naszym przedstawieniom" (Vattimo 2015: 142). Dlaczego ułomność? Bo jest to właśnie bycie słabe, pozbawione stałych fundamentów ontologicznych, nasycone niejednoznacznością, nietożsamością i pewnym rodzajem niedokończenia, które jako „słaba” faktyczność jest zapośredniczone w przygodności.

Wy-darzanie duchowości towarzyszy człowiekowi poprzez posyłanie w darze czegoś, co jest dopiero do odczytu (por. Walczak, Jocz 2019: 99-113). Dar jest czymś prymarnym i sam w sobie nie ma mocy aktywizujących wrażliwość człowieka. Jest impulsem - wyzwalaczem wewnętrznego dialogu. Wdając się z nim w rozmowę, człowiek nadaje temu znaczenia i sam się zmienia. Zmiana - czy tak jak zazwyczaj się określa ten proces w kontekście tak mocnych, jak i słabych interpretacji duchowości jako zmianę/przemianę/przejście - ma charakter procesualny i właśnie dialogiczny. Jest ona rozciągnięta w czasie i wymaga zarazem nieustają-

\footnotetext{
10 Jaromir Brejdak w tym miejscu powołuje się na etymologiczne znaczenie teraźniejszości w języku polskim Aleksandra Brücknera. Pisze, że w języku polskim etymologicznie bardziej źródłowym jest słowo „teraz” niż „tu teraz” czy „teraźniejszość” będące ściągnięciem dwu słów „ten raz”. „Teraz” odsłania sytuacyjność, jak i dziejowość obecności.

11 Por. z ujęciem przygodności Richarda Rorty'ego (2008).
} 
cych konfrontacji z różnymi, często nieprzylegającymi do siebie, odczytywaniami tego, co „posyłane” w darze, ale i odczytywaniami różnych ja w nas samych, często ukrytych, zapomnianych, niechcianych, nieważnych dla nas et cetera i dopiero odkrywanych. Jest to proces, który odbywa się poza życzeniem i wolą człowieka - dlatego i on sam raczej mu się przydarza. Nadawanie mu znaczeń odbywa się zatem na poziomie bardziej intuicji niż świadomości kojarzonej zazwyczaj z samowiedzą o tym, co się z człowiekiem dzieje, jakim zmianom/przemianom/przejściom podlega (ulega) i jakie ma to dla niego znaczenie/znaczenia. Warto również dodać, że procesualność zmiany/przemiany/przejścia - wy-darzania się duchowości - może dokonywać się „bezszelestnie” w sposób wyciszony i niewidoczny dla człowieka, jak o transformacji osobowego doświadczenia zachodzącego zazwyczaj w długim czasie „poprzez to, co nam się zdarza w życiu”, jak również poprzez ponowne podjęcie, wznowienie przeżycia tego, co nam się zdarzyło, mówi François Jullien (za: Marynowicz-Hetka 2019: 94)12. Ale jakby powiedział Meillassoux, tak jak wydarzanie duchowości nie jest konieczne, tak i nie musi być przygodne. Może ono w ogóle nie mieć miejsca w życiu człowieka - i w tym miejscu ujawnia się kruchość relacji człowieka w-obec duchowości.

„Słaba” interpretacja duchowości jest wynikiem zmierzenia się z tym, co nieprzewidywalne i nierozstrzygalne, znikome i jakby resztkowe $\mathrm{w}$ stosunku do „twardego" bycia człowieka w świecie zorientowanym na posiadanie - również na posiadanie siebie jako bytu uduchowionego. Duchowość - nie będąc ani „daną" człowiekowi, ani przesłaniem dla niego - nie obdarowuje człowieka sobą. Duchowość jest tworzona - a raczej wy-twarzana przez człowieka. Człowiek sam zobowiązuje się przed sobą wziąć ją na własne barki - zobowiązuje się zmierzyć się z nią jak mierzyć może się np. z siłami, których nie rozumie, a je przeżywa. Z racji tego, że „bycie” duchowości jest przygodne, dynamiczne, zmienne i otwarte na swoje własne kreacje, duchowość traci w tej interpretacji ciężar ontologiczny. „Słaba” interpretacja duchowości nie mówi ani o unifikacji, ani o pozytywnej waloryzacji przygodnej jej formy bycia - jej wydarzeniowości. Nie można także uznać, że zmiana/przemiana/przejście, które korespondują z wy-darzaniem się duchowości - tak jak i etapowością rozwoju duchowego - mają tylko wymiar pozytywny (por. Socha 2014: 182-204)13 albo względny. Tak jak względne miałoby być bycie duchowości, podobnie jak względnym miałby być świat, dlatego że mówi się o jego wielości - wszak chodzi o jeden i ten sam świat.

\footnotetext{
12 Ramy artykułu nie pozwalają na podjęcie rozważań nad kategorią śladu - znaczących w kontekście rozważań o obecności i nie-obecności duchowości.

13 Obłęd jest bliski olśnieniu, ponieważ może on oślepić. Wymiary zmiany/przemiany duchowej to kwestie, które są istotne dla pogłębienia analiz dotyczących duchowości i możliwości mówienia o niej. W tym artykule nie poruszam jednak doznań szczytowych na granicy lub poza granicą świadomości, a które mieszczą się także w kontekście rozważań o współczesnych interpretacjach duchowości. Wspomnę tylko, że doświadczenie zmiany/przemiany duchowej może być także doświadczeniem obcości siebie - doświadczeniem nieobecnego siebie, odseparowanego od siebie, oddalonego od siebie, nieprzystawalnego do siebie jako rozpoznanej swojości, doświadczeniem dezorientującym człowieka.
} 
Widzę w tym miejscu paralelę ze stanowiskiem M. Merleau-Ponty'ego wobec percepcyjnych możliwości przyswojenia sobie świata i wszystkich jego ekwiwalentów - tak widocznych, jak i niewidocznych. Merleau-Ponty mówi o niemożności takiego przyswojenia, jak również niemożności przyswojenia głębi swojego wewnętrznego świata. Pod powierzchnią tego, co widzialne i nazwane, znajduje się to, co niewidzialne i niepoddające się nazwaniu. Ale pewność, że istnieje jedno i drugie w swych stałych znaczeniach „pozostaje absolutnie niejasna; możemy nią żyć, nie możemy ani jej pomyśleć, ani sformułować, ani podnieść do poziomu tezy" (Merleau-Ponty 1996: 25). Ponadto, to co jest człowiekowi dane w percepcji świata, również wewnętrznego, nie jest tekstem, w którym możliwe jest odkrycie jego ostatecznego sensu, choćby ze względu na zmianę pozycji percepcji - potencjalnej, niewyczerpalnej możliwości innych ujęć widzialnego i niewidzialnego, innych ich przedstawień. I nic tutaj nie jest bytem samym w sobie. Dla Merleau-Ponty'ego percepcja dokonuje się wewnątrz świata w splocie (wymianie) tego, co widzialne i niewidzialne - widzący jest zarazem widzialnym tak jak dotykający jest zarazem tym, kto jest dotykany. Nie można zatem doświadczyć pełni obecności ani tego, co widzialne, ani tego, co niewidzialne.

Dlatego „słaby” język, w którym chcemy coś powiedzieć o duchowości, niewiele mówi o niej samej - nie projektuje jej, nie mówi, że jest tym, co najbardziej przez człowieka pożądane, bo wzbogacające go w jego człowieczeństwie. „Słaby” język nie operuje pewnikami (wartości duchowe, których realizacja ma gwarantować rozwój duchowy). Jest enigmatyczny, nie-dosłowny - metaforyczny, bo cóż znaczy „wy-darzeniowość" duchowości oraz mówienie o duchowości, nie mówiąc o niej w utartych znaczeniowo/konwencjonalnie schematach językowych. Dlaczego np. nie mówi się tutaj o rozwoju duchowości, a o jej wy-darzaniu, gdzie samo słowo wydarzanie wykracza poza zwyczajową konotację zdarzenia. Ponieważ w „słabej” interpretacji nie ma „mocnych” ekwiwalentów językowych w wypowiedzi o duchowości w postaci np. wypowiedzi konkluzywnych, ona sama jest niestała i zmienna - przybiera postać czasującego się wypowiadania. Niekonkluzywny „słaby” język, w którym dokonuje się interpretacja duchowości, animuje kolejne możliwe jej odczytania. Nie dysponując imperatywnymi narzędziami konceptualnymi, dającymi wyczerpujący opis duchowości wraz z „wytycznymi” jej realizacji w życiu, „słaba” interpretacja duchowości staje się mało atrakcyjna dla człowieka, który pyta o siebie samego - „kim jestem i kim mam być?” i oczekującego, jeśli nie drogowskazów, to przynajmniej podpowiedzi.

\section{Zakończenie. Nauki o wychowaniu i duchowość - „przemyślenie” znaczeń}

Choć we współczesnej humanistyce nie jest to stanowisko godne uznania i respektowania, to nauki społeczne wciąż mają do niego słabość. A chodzi o takie stanowisko do nauki, w którym ona sama - zakłada się - musi 
zajmować się tylko tym, co konkretne, a nie tym, co nieokreślone, tylko tym, co jest empiryczne (weryfikowalne), a nie „bojatakuważaniem”; tylko tym, co jest intersubiektywne, a nie tym, co solipsystyczne; tylko tym, co można porównywać, bo jeśli coś jest z niczym nieporównywalne, to ewentualnie może to być sztuka, ale na pewno nie jest to nauka (Bolecki 2011: 8).

Nauki o wychowaniu, które zostały przypisane do dziedziny nauk społecznych, najczęściej są kojarzone z pedagogiką, psychologią i socjologią ${ }^{14}$ oraz z ich subdyscyplinami. Jeśli współcześnie mówi się o kryzysie duchowości i jednocześnie o duchowości bez skonfesjonalizowanej religii, to nurtującym jest pytanie: jaki pożytek mają nauki o wychowaniu - a głównie pedagogika - z tego, że w obrębie ich dyskursów i na pograniczach z innymi przyjmowane jest założenie o znaczeniu dla kondycji ludzkiej sfery duchowej i powiązanego z nią rozwoju duchowego, którą da się rozróżnić - na zasadzie porównania - od innych sfer rozwojowych? Nauki o wychowaniu tradycyjnie wiąże się z ukierunkowaniem na praxis, w związku z czym pojawia się kolejne pytanie: czy wciąż jest możliwe rozwijanie sfery duchowej vel wyzwalanie i stymulowanie rozwoju duchowego przy „zastosowaniu” dotychczasowego „narzędzia”: wprowadzania w świat wartości - wartości duchowych uznanych uprzednio za najwyższe w panteonie wartości, które zostały rozpoznane - „wycenione” i nazwane? Tak określone poddają się badaniom weryfikującym, mimo nieustającego ich wymykania się spod jarzma dookreśloności.

Współczesne nauki humanistyczne, pozostające nadal w związku z tradycyjnymi naukami o duchu Wilhelma Diltheya, uświadamiają względność prawdy o świecie, w którym człowiek żyje - względność tego, co człowiek myśli o nim i co z nim robi. Uważam, że współczesne nauki o wychowaniu ${ }^{15}$, źródłowo zakorzenione w naukach humanistycznych, mogą zająć się tym, co nie(do)określone. Nauki o wychowaniu jako nauki humanistyczne - w hermeneutycznym podejściu do nich Hansa-Georga Gadamera - miałyby za zadanie umożliwienie zrozumienia kultury, w której żyjemy/żyliśmy/będziemy żyć po to, by rozumnie w tej kulturze partycypować (Gadamer 1993: 23-32). W naukach humanistycznych proces rozumienia odgrywa szczególną rolę. Rozumienie jednak nie dotyczy poznawczego uchwycenia mechanizmów czy prawidłowości „rządzących” kulturą - nie sprowadza się zatem do metody badań w tych naukach. Jest ono dla Gadamera podstawowym egzystencjałem ludzkiego bycia-w-świecie i odnosi się do fenomenów tegoż bycia w ich niepowtarzalnym znaczeniu w kontekście różnych procesów kulturowych. Odnosi

\footnotetext{
14 Wśród nauk o wychowaniu - i mieszczących się w zakresie dziedziny nauk społecznych - należy wymienić filozofię i jej subdyscyplinę - filozofię wychowania, filozofię edukacji.

15 Choć nie podejmuję w tym artykule analiz stanu współczesnych nauk o wychowaniu w Polsce, to przywołując je w artykule mam na uwadze nauki o wychowaniu w Polsce.
} 
się zatem do codziennego ${ }^{16}$ doświadczania życia, w całej jego złożoności i różnorodności. Rozumienie jako kluczowa kategoria w naukach humanistycznych nie jest jednak kontemplatywnym jego oglądem, lecz partycypuje w nim przy uprzednim przyjęciu perspektywiczności rozumienia (zawsze jest osadzone w jakimś kontekście kulturowym) i świadomości jego cząstkowości (ujawnia się zawsze jako jedna z możliwych wypowiedzi).

W tym miejscu dokonam krótkiego podsumowania interpretacji „mocnej” i „słabej” duchowości - w moim przekonaniu koniecznego przedmiotu badań nauk o wychowaniu jako nauk humanistycznych partycypujących w kulturze w świecie, który - jak komentował ujęcie świata ducha Heideggera Derrida: „nie jest ziemią. Na ziemi dochodzi do zaciemnienia świata (Heideggerowskiego - A.W. Weltverdüsterung): ucieczki bogów, destrukcji ziemi, umasowienia ludzi, wywyższenia przeciętności. (...) Świat to zawsze świat duchowy” (Derrida 2015: 54).

„Mocna” i „słaba” interpretacja duchowości zakładają specyficzny dla siebie stosunek do tego, co przez człowieka zastane w świecie i co zostawia za sobą. W pierwszym przypadku zastaje się możliwość (na prawach mocy) rozwoju duchowego jako pewną „stałą ludzkiego życia”, mającą formę „podręcznej” w tym znaczeniu, że będącej w zasięgu działań człowieka, których efektem zawsze też może być osiągnięcie dojrzałości duchowej. W drugim przypadku człowiek zastaje przygodność bycia duchowości - coś się wy-darza (dzieje się) i coś może być tegoż wy-darzania (dziania się) efektem, ale zarówno może w ogóle się nie z-(wy)darzyć. W paśmie migotliwych ciągłości i możliwych zerwań znaczeń bycia $\mathrm{w}$ świecie duchowość jest efemerydalna - „żyje” tymczasowo, jakby w „szczelinach” życia codziennego i tylko w sprzyjających warunkach - prymarnej wrażliwości, niezmysłowej, a jednak cielesnej (por. Walczak, Jocz 2019: 40-52). 0 ile duchowość w „mocnej” interpretacji jawi się jako ta, po której śladach się kroczy, o tyle w „słabej” jej interpretacji nie tyle idzie się po śladach, co się je odczytuje - szuka się tego, co ona znaczy. A zatem i jej znaczenia są potencjalnie człowiekowi dane - dane do odczytu, choć zazwyczaj wymykające się i wciąż skrywające, niemożliwe do całkowitego uobecnienia, ogarnięcia, przedstawienia i zastosowania w odpowiedzi na pytanie: „kim jestem i jakim mam być?”.

Interpretacja duchowości jako „stałej ludzkiego życia” - w tym artykule ulokowana na dwóch biegunach interpretacyjnych - jest umocowana w czasowym, historycznym kontekście znaczeniowym, z którym wiązać należy możliwość i ograniczoność recepcji bycia-w-świecie współczesnego człowieka kultury Zachodu. Wykorzystanie w obrębie nauk o wychowaniu tego kontekstu do analiz znaczenia duchowości na bazie porównania z tym, co np. nie jest duchowością, jest zawsze problematyczne. A mimo wszystko przyjmuje się w nich - oczywiście w różnych

\footnotetext{
16 To, co niecodzienne i tak ma miejsce w codzienności. Poza tym, na co zwracała uwagę np. Natalie Depraz, można raczej mówić o płynnym przechodzeniu/ujawnianiu się codzienności i niecodzienności (wyjątkowości) (Depraz 2010: 96).
} 
konfiguracjach koncepcyjnych - zawarte już w założeniach dotyczących sfery duchowej człowieka, objawienie: sfera ta ma znaczenie dla pełnego/najwyższego/ostatecznego rozwoju człowieka. Jest to „mocne” założenie jej obecności i „mocna” jej interpretacja, które warto, aby nauki o wychowaniu umieszczone w kontekście współczesnej humanistyki, „przemyślały”.

Zdaniem Gadamera, każda wypowiedź jest zrozumiała wówczas, gdy jest odpowiedzią na jakieś pytanie. Przy czym odpowiedź udzielona w określonym czasie i będąca zadowalającą, w innym może stać się problematyczną. Znaczącą rolę w procesie nadawania znaczeń temu, o co pytamy, odgrywa bowiem język i jego styl/e. Język nie uczestniczy jednak tylko w odczycie znaczeń rzeczywistości oddziałującej na człowieka - w języku dokonuje się ich interpretacja. W pedagogice, najczęściej kojarzonej z nauką o wychowaniu, wciąż dominuje język „mocny” w wypowiedziach o duchowości, człowieku jako istocie duchowej, sferze duchowej, rozwoju duchowym. W tym języku formułuje się także zakres powinności - jakim powinieneś być, by być, np. mądrym, dobrym, ułożonym obyczajnie, sprawnym fizycznie i ... sprawnym duchowo. W nim też są formułowane dyspozycje dla tych, którzy stają się odpowiedzialni za to, aby inni takimi byli. Powinność przekłada się zatem na cel działań - w tym znaczeniu, że generuje „celodążne” działania pedagogiczne, będąc zarazem ich usprawiedliwieniem. Rozważania nad duchowością mają zatem instrumentalny charakter $w$ stosunku do niej samej jako tego, co jest w świecie, również wtedy, kiedy przyjmując „słabą” optykę, wskazywałoby się na jej wydarzeniową „naturę” i moc/powinność obeznania się z nią. Gadamer uważał, że wówczas uprawia się nie naukę, lecz praktykę kaznodziejską w przebraniu badaczy (Gadamer 1993: 25). W tym miejscu warto przytoczyć ponownie jego słowa, które umieściłam jako jedno z mott artykułu: „(...) za naukowe uważam tylko uznawanie tego, co jest, nie zaś wychodzenie od tego, co powinno lub mogłoby być. W tym sensie staram się (...) rozważać z zasadniczą ogólnością to, co dzieje się zawsze" (tamże: 458).

Aby móc dotrzeć do duchowości jako „stałej ludzkiego życia” w przenikaniu się jej obecności i nie-obecności, czyli aby móc rozumieć ją w jej „nagości”, zakładam, że konieczne jest wywłaszczenie ze zwyczajowych jej konceptualizacji. Odsłonięcie jej „nagości”, czyli uczynienie jej „bezdomnej”, to osłabianie jej obecności, którą człowiek pojmuje jako daną sobie trwałość i wystawienie jej na czasującą się prawdę jej bycia - na zmienne odczyty znaczeń jej bycia. Bycia zapośredniczonego w byciu człowieka-w-świecie splecionego z nietrwałością przejawów tegoż bycia, zatem i nietrwałością przejawów relacyjnego układu człowiek-duchowość, ale przede wszystkim ich nieugruntowania w konieczności bycia dokonanego lub dokonującego się. Znamiennie w tym miejscu wybrzmiewają słowa Constantina Noici: „(...) być znaczy też coś innego niż «jest» w klasycznym sensie: znaczy też: byłoby, mogłoby być, miało być, lecz nie było (choć próbowało)" (Noici za: Zawadzki 2010: 55). 
W powyższym kontekście „usytuowania” nauk o wychowaniu wobec wywłaszczenia duchowości ze zwyczajowych jej konceptualizacji, duchowość może zyskać specjalny status - stanie się kategorią, z której będzie można „wyłuskać” nową pojęciowość. Będzie jednym z pojęć operacyjnych, „które nie tyle rejestrują «obiektywne» cechy uprzednio i niezależnie od analizy istniejącego przedmiotu, co «profilują» samo widzenie, percypowanie tego przedmiotu, jego cechy, funkcje i znaczenia" na nowo, inaczej, w kierunku ponownych odczytań poza jej ujęcie jako „zwyczajowe pojęcie” (Nycz 2017: 18-19)17. Towarzyszy temu „przesunięcie zainteresowania" duchowością utożsamianą zazwyczaj z osobowym rozwojem duchowym jako jej „wytworu” na zainteresowanie się jej procesualnością - dzianiem się tego, co przynosi - a raczej może przynieść - osobową zmianę/przemianę/przejście. Tak ujęta byłaby rozpatrywana nie ze względu na efekty - „wytwór”, „lecz z uwagi na swą wewnętrzną logikę, specyfikę własnej sprawczości i kreatywności" (tamże: 21). Odsłoniłyby się wówczas nowe pola problemowe, inicjując nowe orientacje badawcze, za czym idzie także rekonfiguracja pozycji języka, w którym o duchowości się mówi, dzięki czemu można byłoby rozpoznać inne jej wymiary i cechy. W tym miejscu mam na uwadze przesunięcie językowe - przejście z języka „przywykłego” do pojęć ujętych w definicje, z języka opisującego i stwierdzającego w obszar języka problematyzującego (również obecne pojęcia, w tym właśnie duchowość, rozwój duchowy et cetera) i poszukującego (pytającego) (por. Bieszczad 2013: 199-203). To także przesunięcie w stronę języka metaforycznego, który w sposób specyficzny tworzy się wówczas, gdy - jak pisał o tym Józef Tischner - myśli się „z wnętrza metafory” (Tischner 2011: 510-526). A jeśli nawet przesunięcie wydawać się może zbyt radykalnym zabiegiem reformatorskim w naukach o wychowaniu (być może z góry skazanym na niepowodzenie przez siłę przyzwyczajenia do tego, co obeznane), to warto rozważyć kohabitację języka „mocnego" i „słabego”.

Otwiera się wówczas możliwość zadania innych pytań o duchowość - przejście od pytań: „co to jest duchowość i co ona znaczy?” (głównie dla kondycji ludzkiej egzystencji) do pytań o to, „co ona z nami robi lub może zrobić?”, czyli „w jaki sposób dzieje się doświadczenie duchowości i co dzieje się z człowiekiem, który jej doświadcza?" (zob. Walczak, Jocz 2019: 24-33). Interpretacje duchowości - również te, które oscylując między ich „mocną” i „słabą” wersją - wyrażają tylko to, co jest możliwe do „uchwycenia” ze splotu obecności i nieobecności duchowości. Parafrazując przytoczone wcześniej słowa Ricoeura: jej sposób bycia w świecie, w którym obecny jest człowiek, istnieje tylko przez jego jej rozumienie, a jego dziejowość wskazuje, że rozumiemy o tyle, o ile rozumiemy inaczej w stosunku do zastanych form rozumienia.

\footnotetext{
17 Określenie „zwyczajowe pojęcia” zaczerpnęłam od Jeana-Marie Barbiera, który jest twórcą Leksykonu analizy aktywności. Konceptualizacje zwyczajowych pojęć. Przedstawia w nim, często nie-zwyczajowe, znaczenia pojęć powiązanych z kluczowym dla niego pojęciem aktywności. Można je potraktować jak drogowskazy analizy aktywności - narzędzia służące jej rozumieniu poza utartymi kulturowo znaczeniami i do których przywykło ludzkie myślenie (Barbier 2016).
} 


\section{Post scriptum}

W kontekście powyższych rozważań warta odnotowania jest wypowiedź Ferrarisa, którą traktuję jako komentarz do przytoczonej na początku artykułu wypowiedzi Szahaja: „rzeczywistość sama w sobie jest niepoznawalna, zaś poznawalne jest tylko to, co sami do niej wnosimy":

(...) bycie pozostanie, jako takie, poza sferą interpretacji, bo inaczej zabraknie minimalnej, lecz zasadniczej różnicy między rzeczywistością a wyobraźnią (różnicy, na którą zwykle stawiamy wszystko) (...). Rzeczywistość (...) pozostaje poza konceptualnymi schematami i jest od nich niezależna, na tej samej zasadzie, na której nie możemy samą tylko siłą refleksji skorygować iluzji optycznych albo zmienić koloru otaczających nas przedmiotów. Jeśli myślisz, że nie ma faktów, tylko interpretacje, to skąd wiesz, że zmieniasz świat, a nie tylko po prostu wyobrażasz sobie, że go zmieniasz, marząc, że to robisz? (Ferraris 2015: 225, 228-229).

Pamiętać także wypada, że interpretacja - czy „mocna”, czy „słaba” - skrywa albo nie ujawnia tego, co niewysłowione. Zatem i niewypowiedzialne, o czym wszelka postać mówienia może tylko napomykać.

\section{Bibliografia}

Ball M. (2013) Wędrujące pojęcia w naukach humanistycznych. Krótki przewodnik, tłum. M. Bucholc, Warszawa, Narodowe Centrum Kultury.

Baniak J. (red.) (2012) Duchowość religijna jako droga wewnętrznego doskonalenia współczesnego człowieka zachodniego chrześcijaństwa. Konteksty antropologiczne i socjologiczne, Toruń, Wydawnictwo Adam Marszałek.

Barbier J.-M. (2016) Leksykon analizy aktywności. Konceptualizacje zwyczajowych pojęć, tłum. E. Marynowicz-Hetka, Łódź, Wydawnictwo Uniwersytetu Łódzkiego.

Bieszczad B. (2013) Pedagogika i język. Perspektywa ponowoczesna, Kraków, Wydawnictwo Uniwersytetu Jagiellońskiego.

Bolecki W. (2011) O humanistyce inaczej, „Teksty Drugie”, nr 6, s. 6-12.

Cioran E. (2015) Zarys rozkładu, tłum. M. Kowalska, Warszawa, Wydawnictwo Aletheia.

Depraz N. (2010) Zrozumieć fenomenologię. Konkretna praktyka, tłum. A. Czarnacka, Warszawa, Oficyna Wydawnicza. 
Derrida J. (2015) O duchu. Heidegger i pytanie, tłum. B. Brzezicka, Warszawa, Wydawnictwo Naukowe PWN.

Dybel P. (2012) Oblicza hermeneutyki, Kraków, Universitas.

Ferraris M. (2015) Hermeneutyka w: Myśl mocna, myśl słaba. Hermeneutyka włoska od połowy XX wieku. Antologia tekstów, M. Surma-Gawłowska, A. Zawadzki (red.). Kraków, Księgarnia Akademicka, s. 209-225.

Gadamer H.-G. (1993) Prawda i metoda. Zarys hermeneutyki filozoficznej, tłum. B. Baran, Kraków, inter esse.

Geertz C. (2003) Zastane światło. Antropologiczne refleksje na tematy filozoficzne, tłum. i wstęp Z. Pucek, Kraków, Universitas.

Grzegorczyk A., Sójka J., Koschany R. (red.) (2006) Fenomen duchowości, Poznań, Wydawnictwo UAM.

Dybel P. (2012) Oblicza hermeneutyki, Kraków, Universitas.

Jung C. G. (2020) Psychologia a religia Zachodu i Wschodu, tłum. R. Reszke, Warszawa, Wydawnictwo KR.

Leszczyńska K., Pasek Z. (red.) (2008) Nowa duchowość w społeczeństwach monokulturowych i pluralistycznych, Kraków, NOMOS.

Maldijeva V. (2019) Językowe szaty duchowości, Toruń, Wydawnictwo Naukowe Uniwersytetu Mikołaja Kopernika w Toruniu.

Marynowicz-Hetka E. (2019) Pedagogika społeczna. Pojmowanie aktywności w polu praktyki, Łódź, Wydawnictwo Uniwersytetu Łódzkiego.

Meillassoux Q. (2015) Po skończoności. Esej o koniecznej przygodności, tłum. P. Herbich, Warszawa, Fundacja Augusta Hrabiego Cieszkowskiego.

Merleau-Ponty M. (1996) Widzialne i niewidzialne, tłum. M. Kowalska, J. Migasiński, R. Lis, I. Lorenc, Warszawa, Fundacja Aletheia.

Nycz R. (2017) Kultura jako czasownik. Sondowanie nowej humanistyki, Warszawa, Wydawnictwo Instytutu Badań Literackich PAN.

Pareyson L. (2015) Konieczność zwrotu ku mitowi. Sztuka i religia w: Myśl mocna, myśl słaba. Hermeneutyka włoska od połowy XX wieku. Antologia tekstów, M. Surma-Gawłowska, A. Zawadzki (red.), Kraków, Księgarnia Akademicka, s. 101-110. 
Ricoeur P. (1989) Język, tekst, interpretacja. Wybór pism, tłum. P. Graff, K. Rosner, Warszawa, Państwowy Instytut Wydawniczy.

Ricoeur P. (2004), Drogi rozpoznania. Wykłady Instytutu Nauk o Człowieku w Wiedniu, tłum. J. Migasiński, Kraków, Wydawnictwo Znak.

Ricoeur P. (2008) Czas i opowieść. Czas opowiadany, t. III, Kraków, Wydawnictwo Uniwersytetu Jagiellońskiego.

Rorty R. (2008) Przygodność, ironia i solidarność, tłum. W. J. Popowski, Warszawa, W.A.B.

Socha P. (2014) Przemiana. W stronę teorii duchowości, Kraków, NOMOS.

Straś-Romanowska M., Bartosz B., Żurko M. (red.) (2010) Psychologia małych i wielkich narracji, Warszawa, Eneteia.

Surma-Gawłowska M., Zawadzki A. (red.) (2015) Myśl mocna, myśl słaba. Hermeneutyka włoska od połowy XX wieku. Antologia tekstów, Kraków, Księgarnia Akademicka.

Szahaj A. (2012) Siła i słabość hermeneutyki, „Teksty Drugie”, nr 1-2, s. 87-94.

Szajnert D. (2006) Intencja versus inwencja. Dylemat etyczny?, „Teksty Drugie”, nr 1-2, s. 58-86.

Tischner J. (2011) Myślenie z wnętrza metafory w: J. Tischner, Myślenie według wartości, Kraków, Wydawnictwo Znak, s. 510-526.

Vattimo G. (2011) Poza interpretacja. Znaczenie hermeneutyki dla filozofii, tłum. K. Kasia, Kraków, Universitas.

Vattimo G. (2015) Dialektyka, różnica, myśl słaba w: Myśl mocna, myśl słaba. Hermeneutyka włoska od połowy XX wieku. Antologia tekstów, M. Surma-Gawłowska, A. Zawadzki (red.), Kraków, Księgarnia Akademicka, s. 133-148.

Walczak A., Jocz. A. (2019) Doświadczenie duchowości. Konteksty filozoficzno-literackie, Łódź, Wydawnictwo Uniwersytetu Łódzkiego.

Wittgenstein L. (2012) Dociekania filozoficzne, tłum. B. Wolniewicz, Warszawa, Wydawnictwo Naukowe PWN.

Wojtysiak J. (2005), O słowie BYĆ. Z teorii wyrażeń egzystencjalnych i ich filozoficznego zastosowania, Lublin, Towarzystwo Naukowe KUL.

Zawadzki A. (2010) Literatura a myśl słaba, Kraków, Universitas. 